Original Research Paper

\title{
Assessment of Type 2 Anti-Diabetes on Bound Flavonoids of Barringtonia racemosa (L.) Spreng. Kernel in Glucose- Induced Diabetic Rats
}

\author{
${ }^{1}$ Musri Musman, ${ }^{1}$ Emelda Audina, \\ ${ }^{1}$ Fazlia Inda Rahmayani Ratu, ${ }^{1}$ Erlidawati Erlidawati and ${ }^{2}$ Safrida Safrida \\ ${ }^{I}$ Department of Chemistry Education, \\ ${ }^{2}$ Department of Biology Education, \\ Faculty of Teacher Training and Education, \\ Syiah Kuala University, Darussalam - Banda Aceh, Indonesia, 23111, Indonesia
}

Article history

Received: 08-10-2017

Revised: 02-11-2017

Accepted: 16-12-2017

Corresponding Author:

Musri Musman

Department of Chemistry

Education, Faculty of Teacher

Training and Education, Syiah

Kuala University, Darussalam -

Banda Aceh, Indonesia, 23111,

Indonesia

Tel: +6285260525207

Email: musrimusman@gmail.com

\begin{abstract}
A study of type 2 anti-diabetes on bound flavonoids fraction from the kernel of Barringtonia racemosa (L.) Spreng. in glucose-induced diabetic rats was performed. This learning aimed to gather scientific information about the possibility to utilize kernel of $B$. racemos $a$ as a raw material of antidiabetic drug. The antioxidant property of the bound flavonoids was determined by the DPPH scavenging method compared to the ascorbic acid. Assessment of type 2 anti-diabetes was conducted on glucose-induced diabetic Rattus norvegicus Wistar strain compared to metformin and the data were analyzed through one-way ANOVA software. Histopathological studies of the pancreas and kidney were made to get evidence of the $\beta$-cell performance and the renal tissue respectively. The DPPH testing at the wavelength of $517 \mathrm{~nm}$ showed the bound flavonoids and the ascorbic acid showed absorbance at 0.097 and 0.080 correlated with $\mathrm{IC}_{50}$ values of 7.51 and $6.50 \mathrm{ppm}$ respectively. The results of one-way ANOVA indicated that the administration of bound flavonoids was significant $(F(2,11)=8.60, \mathrm{p}=0.008)$ to reduce blood glucose level in the tested rats. The diabetic rats treated with the extract experienced an antidiabetic effect equivalent to an antidiabetic effect of metformin. Histopathologic observations showed increasing of the granulated $\beta$-cell $(F(3,15)=26.09, \mathrm{p}<0.0001)$ and no renal tissue damage $(F(3,15)=0.23, \mathrm{p}$ $=0.873)$ in the tested rats. The conclusion raised from the data of this study revealed that the bound flavonoids from the kernel of B. racemosa (L.) Spreng. could be utilized as a drug source of type 2 anti-diabetes.
\end{abstract}

Keywords: Barringtonia racemosa, Antidiabetic Drug, Bound Flavonoid, DPPH, Antioxidant Property

\section{Introduction}

The WHO report stated that diabetes is a very important public health matter to address and requires serious business and positive responses from various sectors such as government, civil society and diabetic people, food makers, pharmaceutical manufacturers and medical technology (WHO, 2016). The current findings indicate strong evidence that type 2 diabetes is nearly linked to oxidative stress (Ceriello and Motz, 2004; Pham-Huy et al., 2008; Chikezie et al., 2015;
Ullah et al., 2016; Das et al., 2016) that accumulates due to the body's incapability to balance the formation of oxidants (free radicals) with the availability of reductants (antioxidants). Free radicals of Reactive Oxygen Species (ROS) can occur due to metabolic activities in the body (Wolff, 1993; Maddux et al., 2001; Devasagayam et al., 2004; Wright Junior et al., 2006), ultraviolet radiation, pesticides in food and other pollutants (Bagchi and Puri, 1998; Betteridge, 2000; Brownlee, 2001; Yoshikawa and Naito, 2002; Bansal and Bilaspuri, 2011). 
ROS are formed in the nucleus and also in the cell membrane where it destroys biologically relevant molecules such as DNA, proteins, sugars and lipids (Young and Woodside, 2001). ROS have been concerned with the initiation and complications of diabetes mellitus (Martin et al., 2003; Yung et al., 2006; Iqbal et al., 2016). Excessive ROS production causes damage to cells and cell tissues. To halt the production of ROS, a compound that has the property of free radical deactivation is required. The amount of ROS (oxidants) formed in cell tissues must be balanced with the availability of antioxidants. Therefore, the administration of external sources of antioxidants can be applied in managing the ROS (Halliwell, 1995; Laight et al., 2000; Kangralkar et al., 2012; Santos-Buelga and Feliciano, 2017).

One of the secondary metabolites that have antioxidant property is flavonoid (Pietta, 2000; Rice-Evans, 2001; Heim et al., 2002). Flavonoids are phenolic glycoside compounds widely found in plants (Hahlbrock, 1981, Ferreyra et al., 2012) and microorganisms (Das and Rosazza, 2006; Wang et al., 2011). Flavonoids have the ability to reduce the formation of free radicals and to scavenge free radicals (Rice-Evans et al., 1996; 1997; Amić et al., 2003; Ganesan et al., 2016). Consequently, the exploration for phyto-nutraceutical substances with antioxidative activity has been exaggerated in recent years (Lobo et al., 2010; Pandeya et al., 2013) mainly in connection with type 2 diabetes (Jakus, 2000; Montonen et al., 2004; Kamalakkannan and Prince,
2006; Pandey and Rizvi, 2009; Dewanjee et al., 2011; Wedick et al., 2012; Babu et al., 2013; Kan et al., 2015; Li et al., 2016).

Nature has provided medicinal materials in its surroundings. Humans have and will exploit the medicinal plants to cope with the illness, i.e., Barringtonia racemosa (L.) Spreng. The plant is an evergreens mangrove association that has been used as an ethnomedicinal agent to treat a number of illnesses as shown in Table 1. Outstanding to its wide range of ethnopharmacological applications, researchers have devoted their attention to finding out the pharmacological activities of the plant as revealed in Table 2 which may be used as a source of medicinal substances. Considering the presence of secondary metabolites in B. racemosa seeds as disclosed in Table 2, the exploitation of the bound flavonoids to manage type 2 diabetes mellitus interest to be investigated. The bound flavonoids have demonstrated very strong antioxidant activity, high bioavailability and more ready absorbed in metabolism (Nijveldt et al., 2001; Kumar and Pandey, 2013). Based on data searching via the internet, information concerning to bioactive property as type 2 anti-diabetes originating from $B$. racemosa can not be found (Hasan et al., 2000; Sun et al., 2006; Gowri et al., 2009; Lim, 2012; Osman et al., 2015; Nazaruk and Borzym-Kluczyk, 2015; Das et al., 2016; RIRDC, 2017). Therefore, this study was the first investigation of type 2 antidiabetic property derived from the plant.

Table 1: Ethnopharmacological uses of B. racemosa

\begin{tabular}{lll}
\hline Part of the plant used & Treatment & Reference \\
\hline leaves & high blood pressure, itchiness, chickenpox & Kabir et al. (2013; Osman et al., 2015). \\
leaves & itch, chickenpox, rheumatism febrifuge & Lim (2012). \\
seeds & Tumors & Thomas et al. (2002). \\
seeds, barks & fish poison & Manjunath (1948). \\
seeds & colic, parturition, vermifuge, febrifuge & Jayaweera (1981). \\
fruits & poison wild pigs & Manjunath (1948). \\
fruits & hemicrania, ophthalmia, coughs, asthma, diarrhea & Nadkarni (1976). \\
fruits & coughs, asthma, diarrhea, eczema & Jayaweera (1981). \\
fruits, barks & fish poison & Giesen et al. (2007). \\
barks & Insecticide & Manjunath (1948). \\
barks & fish poison, skin diseases & Jayaweera (1981). \\
roots & deobstruent, relief in stomachache. & Jayaweera (1981). \\
\hline
\end{tabular}

Table 2: Pharmacological activity of B. racemosa

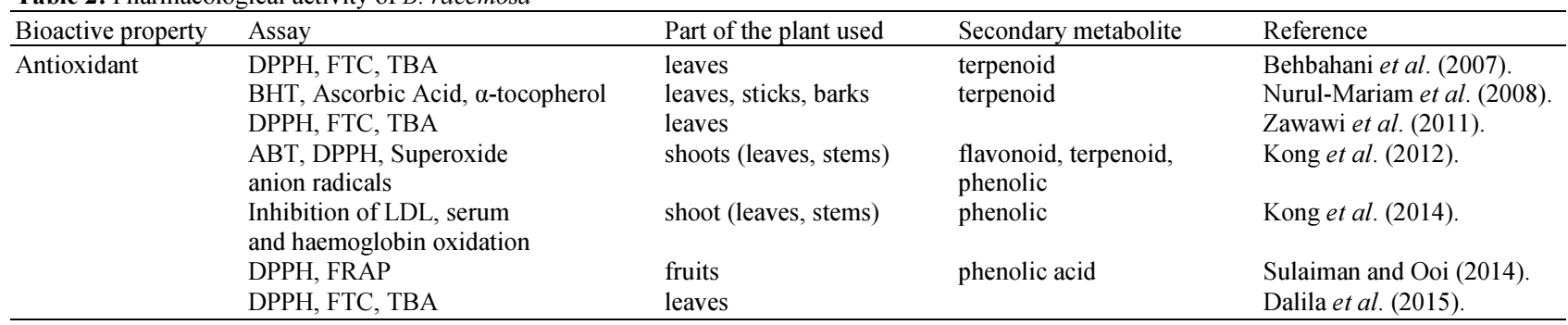




\begin{tabular}{|c|c|c|c|c|}
\hline & $\begin{array}{l}\mathrm{H}_{2} \mathrm{O}_{2} \text {-induced cytotoxicity, } \\
\text { Human HepG2 cells }\end{array}$ & shoots (leaves, stems) & phenolic acid & Kong et al. (2016a). \\
\hline & Human HepG2 cells & shoots (leaves, stems) & & Kong et al. (2016b). \\
\hline & DPPH & fruits & flavonoid, phenolic & Amran et al. (2016). \\
\hline Antibacterial & $\begin{array}{l}\text { Bacillus cereus; Salmonella typhy } \\
\text { Staphylococcus aureus, } \\
\text { Staphylococcus epidermidis, } \\
\text { Eschericia coli, Shigella dysentriae, } \\
\text { Vibrio cholerae, Proteus sp. }\end{array}$ & $\begin{array}{l}\text { root } \\
\text { barks }\end{array}$ & terpenoid & $\begin{array}{l}\text { Khan et al. (2001). } \\
\text { Saha et al. (2013). }\end{array}$ \\
\hline Antimycobacterial & Mycobacterium smegmatic & leaves & & Mmushi et al. (2010). \\
\hline Antifungus & $\begin{array}{l}\text { Fusarium sp., Tricoderma koningii, } \\
\text { Penicillium sp., Ganoderma tropicum, } \\
\text { Ganoderma lucidum, Aspergillus sp., } \\
\text { Rhizopus sp. }\end{array}$ & leaves, sticks, barks & flavonoid, phenolic & Hussin et al. (2009). \\
\hline & Saprolegnia sp. & kernel & flavonoid, saponin & Musman et al. (2015). \\
\hline \multirow{5}{*}{ Anti-inflammatory } & NO inhibition & leaves & terpenoid & Behbahani et al. (2007). \\
\hline & $\begin{array}{l}\text { Carrageenan-induced paw } \\
\text { oedema, Formalin-induced } \\
\text { paw oedema in albino rats. }\end{array}$ & fruits & terpenoid & Sikha et al. (2010). \\
\hline & $\begin{array}{l}\text { Carrageenan-induced acute } \\
\text { inflammation in rats }\end{array}$ & fruits & terpenoid & Patil et al. (2011). \\
\hline & $\begin{array}{l}\mathrm{XO} \text { and albumin } \\
\text { denaturation inhibition }\end{array}$ & $\begin{array}{l}\text { inflorescence axes, } \\
\text { endosperms, leaves, } \\
\text { pericarps }\end{array}$ & & Osman et al. (2016). \\
\hline & DTH model in mice & fruits & terpenoid & Patil and Patil (2016). \\
\hline Anti-arthritic & CFA-induced arthritis rats & fruits & terpenoid & Patil et al. (2011). \\
\hline \multirow{4}{*}{$\begin{array}{l}\text { Anti-diarrhoeal } \\
\alpha \text {-glucosidase inhibitor }\end{array}$} & Inhibition of defecation & barks & & Saha et al. (2013). \\
\hline & $\begin{array}{l}\text { Yeast and intestinal } \\
\alpha \text {-glucosidase inhibition }\end{array}$ & seeds & terpenoid & Gowri et al. (2007). \\
\hline & $\alpha$-glucosidase inhibition & fruits & phenolic & Sulaiman and Ooi (2014). \\
\hline & Saccharomyces cerevisiae & fruits & terpenoid & Ponnapalli et al., 2015. \\
\hline Piscicide & Clarias lazera, Tilapia nilotica & pericarps, seeds & & Adewunmi et al. (2001). \\
\hline \multirow[t]{4}{*}{ Molluscicide } & Biomphalaria glabrata & pericarps, seeds & & Adewunmi et al. (2001). \\
\hline & Biomphalaria pfeifferi & fruits, seeds & triterpenoid saponin & Ojewole et al. (2004). \\
\hline & Pomacea canaliculata & kernel & flavonoid, saponin & Musman (2010). \\
\hline & Cerithidea cingulata & kernel & flavonoid, saponin & Musman et al. (2014). \\
\hline Antihatching eggs & Pomacea canaliculata eggs & kernel & flavonoid, saponin & Musman et al. (2013). \\
\hline Larvicide & $\begin{array}{l}\text { Aedes aegypti larvae } \\
\text { Anopheles arabiensis larvae }\end{array}$ & $\begin{array}{l}\text { pericarps, seeds } \\
\text { fruits, seeds }\end{array}$ & & $\begin{array}{l}\text { Adewunmi et al. (2001). } \\
\text { Ojewole et al. (2004). }\end{array}$ \\
\hline Cercariacide & Biomphalaria pfeifferi & fruits, seeds & flavonoid, terpenoid & Ojewole et al. (2004). \\
\hline Antiplasmodial & Plasmodium falciparum D10 strain & fruits, seeds & the flavonoid, terpenoid & Ojewole et al. (2004). \\
\hline \multirow[t]{2}{*}{ Analgesic } & Albino male rats & barks & phenolic, steroid & Deraniyagala et al., 2003. \\
\hline & $\begin{array}{l}\text { Acetic acid-induced } \\
\text { writhing response, } \\
\text { Anti-lipid peroxidation }\end{array}$ & fruits & terpenoid & Sikha et al. (2010). \\
\hline Immunomodulatory & DTH on SRBCs and & fruits & & Patil et al. (2013). \\
\hline properties & $\begin{array}{l}\text { Humoral antibody } \\
\text { response to SRBC }\end{array}$ & & & \\
\hline $\begin{array}{l}\text { Immune system } \\
\text { disorders }\end{array}$ & $\begin{array}{l}\text { NBT, Phagocytosis, } \\
\text { Candidacidal, Chemotaxis }\end{array}$ & fruits & & Patil et al. (2014). \\
\hline \multirow[t]{7}{*}{ Cytotoxic } & Mouse lymphocyte & stem barks & & Tachibana et al. (1996). \\
\hline & HeLa cells & leaves & & Mackeen et al. (1997). \\
\hline & DLA cells & seeds & & Thomas et al. (2002). \\
\hline & Cancer cells proliferation & leaves & & Chan et al. (2017). \\
\hline & $\begin{array}{l}\text { JURKAT, MOLT-3, REH, } \\
\text { K562, PBMC cell lines }\end{array}$ & fruits & flavonoid glycoside & Samanta et al. (2010). \\
\hline & $\begin{array}{l}\text { MDA-MB- } 231 \text {, A- } 549 \text {, } \\
\text { Hela, K562 cell lines }\end{array}$ & fruits & terpenoid & Ponnapalli et al. (2015). \\
\hline & MTT & fruits & the flavonoid, phenolic & Amran et al. (2016). \\
\hline
\end{tabular}

DPPH: Diphenyl Picryl Hydroxyl, FTC: Ferric Thiocyanate, TBA: Thiobarbituric Acid, BHT: Butylated Hydroxytoluene, ABT: Antigen Binding Test, LDL: Low Density Lipoprotein, FRAP: Ferric Reducing Antioxidant Potential, $\mathrm{H}_{2} \mathrm{O}_{2}$ : Hydrogen peroxide, HepG2: human Hepatocellular carcinoma cells, NO: Nitric Oxide, XO: Xanthine Oxidase, DTH: Delayed-Type Hypersensitivity, CFA: Complete Freund's Adjuvant, SRBCs: Sheep Red Blood Cells, NBT: Nitroblue Tetrazolium, HeLa: Henrietta Lacks, DLA: Dalton's Lymphoma Ascites, JURKAT: Human leukemic T-cell lymphoblast, MOLT-3: Human acute T lymphoblastic leukaemia, REH: Human Pre-B cell leukemia cell line, K562: Human chronic myelogenous leukemia, PBMC: Peripheral Blood Mononuclear Cell, MDA-MB-231: Human breast adenocarcinoma cell line, A-549: Human lung carcinoma cell line, MTT: 3-(4,5-dimethylthiazole-2-yl)-2,5-diphenyl tetrazolium bromide 


\section{Materials and Methods}

\section{Chemicals, Drug and Kit}

All of the analytical grade chemicals, drug and the kit were procured commercially. The metformin hydrochloride $\left(\mathrm{C}_{4} \mathrm{H}_{11} \mathrm{~N}_{5}\right.$, Dexa Medica, Indonesia) was decided as a positive control of the antidiabetic drug. The tested-diabetic rats were induced by the glucose monohydrate $\left(\mathrm{C}_{6} \mathrm{H}_{12} \mathrm{O}_{6}\right.$, Merck, Germany). The Nesco Multicheck (Gesunde Medical, Indonesia) was operated to measure the blood glucose level of the tested rats.

\section{Sample Collection}

The old fruit that has been loose from its stem was collected from Lampuuk (5 31' 56" N 95 24' 00” E) village of Kuta Baro SubDistrict, Aceh Besar District of Aceh Province on October 15th, 2015. The specimen was authenticated by a plant taxonomist of Syiah Kuala University under code MM-015102015.

\section{Preparation of Fruit Sample}

The collected fruits $(1.50 \mathrm{~kg}$, gross weight $)$ were decorticated to pick kernels up. The kernels $(0.65 \mathrm{~kg}$, gross weight) were cut into thin slices and then air dried under shade for seven days. The thin slices of a dried kernel $(0.20 \mathrm{~kg}$, dry weight $)$ were ground with an electric blender and sieved with $40 \mathrm{~mm}$ mesh sieve to get a fine powder. The powder was stored in a dark bottle at room temperature until used.

\section{Extraction of Bound Flavonoids}

The procedure of Subramanian and Nagarajan (1969) was applied in order to obtain the bound flavonoid substances. The kernel powder was Soxhlet extracted with $96 \%$ (v/v) ethanol (EtOH, $100 \mathrm{~mL} \mathrm{~g}^{-1}$ dry weight) for $24 \mathrm{~h}$ and then concentrated under vacuum at $45^{\circ} \mathrm{C}$. The concentrated extract was further fractioned in series petroleum ether (pet ether), diethyl ether $\left(\mathrm{Et}_{2} \mathrm{O}\right)$ and ethyl acetate (EtOAc). The ethyl acetate fraction was hydrolyzed by refluxing with $7 \%$ sulphuric acid $\left(\mathrm{H}_{2} \mathrm{SO}_{4}\right.$, $10 \mathrm{~mL} \mathrm{~g}^{-1}$ residue) for two hours and then the filtrate was extracted with the ethyl acetate solvent. The obtained fraction was washed with distilled water to neutrality and dried by laying in a vacuum desiccator. The bound flavonoids extract was stored in the labeled bottle for the next step.

\section{Phytochemical Analysis of Bound Flavonoids}

The secondary metabolites of the bound flavonoids extract were carried out by means of standard laboratory for phytochemical screening (Banu and Cathrine, 2015). The alkaloids were examined through the Dragendorff's tests, the Mayer's and the Wagner's (Evans, 2009), the flavonoid constituents were investigated by the Shinoda's test (Raaman, 2006), the phenolic components were evaluated by the ferric chloride test (Sangeetha et al.,
2014), the saponin constituents were noticed via the frothing test (Evans, 2009), the tannins were assessed through the ferric chloride and the alkaline tests (Evans, 2009) and the terpenoids were studied over the Liebermann-Burchard's test (Harborne, 1998).

\section{DPPH Assay}

The DPPH (2,2-diphenyl-1-picrylhydrazyl, $\mathrm{C}_{18} \mathrm{H}_{12} \mathrm{~N}_{5} \mathrm{O}_{6}$ ) procedure (Huang et al., 2005) was applied to evaluate the antioxidant activity of the bounded flavonoids extract. The ascorbic acid was preferred as the standard of the antioxidant and the trial was set up in triplicate. A $10 \mathrm{~mL}$ of $0.1 \mathrm{mM}$ methanolic DPPH solution was prepared. A control solution was made by adding $3.5 \mathrm{~mL}$ of $96 \%$ methanol (MeOH) to $0.5 \mathrm{~mL}$ of the DPPH solution. The tested extract was dissolved in the $96 \%$ methanol at five different concentrations, e.g., 2, 4, 6, 8 and $10 \mathrm{ppm}$. A three $\mathrm{mL}$ of each the methanolic tested extract solution was mixed with one $\mathrm{mL}$ of the DPPH solution. The mixture was homogenized and kept standing at room temperature for $30 \mathrm{~min}$. The wavelength of $517 \mathrm{~nm}$ was set to measure absorbance by using UV-Vis Spectronik 20D ${ }^{+}$single-beam Spectrophotometer (Thermo Fisher Scientific, USA). The percentage inhibition of antioxidant activity was designed through the formula: Inhibition $(\%)=\left\{\left(\mathrm{A}_{0^{-}}\right.\right.$ $\left.\left.A_{1}\right) / A_{0}\right\} \times 100$, where $A_{0}$ was the absorbance of the ascorbic acid and $A_{1}$ was the absorbance of the extract (Hossain et al., 2016). The $\mathrm{IC}_{50}$ value of the tested extract was calculated through the log dose inhibition curve.

\section{In Vivo Experiment}

The healthy adult Rattus norvegicus (200-250 g body weight) Wistar fatty strain (Abdul-Ghani and DeFronzo, 2010) were conditioned in a cage (Alexandru, 2011; Fawcett, 2012) for a week. After a week adaptation, a dozen rat was separated into four groups by setting: The negative control group (marked as NC group), the positive control group (marked as PC group), the dose of $100 \mathrm{mg} \mathrm{kg}{ }^{-1}$ body weight group (marked as BF1 stands for the bound flavonoids extract at a dose of $100 \mathrm{mg} \mathrm{kg}^{-1}$ b.wt.) and the dose of $200 \mathrm{mg} \mathrm{kg}^{-1}$ body weight group (marked as BF2 stands for the bound flavonoids extract at a dose of $200 \mathrm{mg} \mathrm{kg}^{-1}$ b.wt.). Individual rat in each group was collected its blood on the 7th day and marked as a pre-treatment blood. The diabetic rat was generated by giving orally one $\mathrm{mL}$ of $50 \%(\mathrm{w} / \mathrm{v})$ aqueous glucose monohydrate to each rat in each group (Arul et al., 2006) on the 8th and the 11th days. After a week since the glucose given, the blood was collected from individual rat to check the diabetic rat according to the value blood glucose level $\geq 200 \mathrm{mg} \mathrm{dL}^{-1}$ (ADA, 2015). This blood was noticeable as the blood obtained before treatment. After finding out the diabetic rat, all rats were given orally: The aqueous metformin of $65 \mathrm{mg} \mathrm{kg}$ weight in PC group, the aqueous tested extract of 100 $\mathrm{mg} \mathrm{kg}{ }^{-1}$ body weight in BF1 group and the aqueous 
tested extract of $200 \mathrm{mg} \mathrm{kg}^{-1}$ body weight in BF2 group respectively every day at 10 a.m. for seven days. Later on this point, the individual rat in each group was collected its blood. The blood was noticeable as the blood obtained after treatment. One day later, a rat in each group was selected to be sacrificed for histopathological observation on the kidney and pancreas organs. The difference of blood glucose level was stated as an antidiabetic effect. The percentage of antidiabetic effect was calculated by the formula: Antidiabetic effect $(\%)=\{(a-b) / a\} \times 100$, where a was blood glucose level of rat obtained before treatment and b was blood glucose level of rat obtained after treatment (Candasamy et al., 2014).

\section{Histopathological Study}

The kidney and pancreas organs were submerged in Neutral Buffered Formalin for a week and then histopathological investigations were performed (Spitalnik, 2016). The slices were tainted with Hematoxylin Eosin (HE) and studied under DP12 Olympus binocular research microscope.

\section{Statistical Analysis}

One-way ANOVA was performed using the SPSS software version 24 (IBM Corp., Armonk, New York, USA) and the SAS software version 9.1.3 (SAS Institute
Inc., Cary, NC, USA) to assess the effect of bound flavonoids of $B$. racemosa kernel on blood glucose level of glucose-induced diabetic rats. The values were stated statistically significant difference when the $\mathrm{p}$ value $<$ 0.05 following Duncan's post hoc test for comparing the treatments (Steel et al., 1997).

\section{Results}

\section{Phytochemical Analysis}

The results of the phytochemical analysis of the bound flavonoid extract showed only flavonoid components as disclosed in Table 3.

\section{Antioxidant Evaluation}

The bounded flavonoids extract was run to antioxidant evaluation over DPPH radical scavenging method. At the wavelength of $517 \mathrm{~nm}$, the absorbances of 0.080 and 0.097 for the ascorbic acid and the extract respectively were observed as shown in Table 4.

\section{In Vivo Experiment}

The in vivo experiment on the glucose-induced diabetic rats shown decreasing the blood glucose level along with increasing dose of the extract as shown in Table 5 .

Table 3: Phytochemical screening of the bound flavonoids of B. racemosa kernel

$$
\text { Secondary metabolite }
$$

\begin{tabular}{llllll} 
Extract & Alkaloid & flavonoid & phenolic & saponin & tannin \\
\hline Bound flavonoids fraction & - & +++ & - & - & -
\end{tabular}

Note: - stands for absent, +++ stands for present in a high levels

Table 4: The $\mathrm{IC}_{50}$ value of the bound flavonoids of $B$. racemosa kernel with reference to ascorbic acid

\begin{tabular}{|c|c|c|c|c|c|c|c|}
\hline \multirow[b]{2}{*}{$\begin{array}{l}\text { Control } \\
\text { (A) }\end{array}$} & \multirow[b]{2}{*}{$\begin{array}{l}\text { Concentration } \\
(\mathrm{ppm})\end{array}$} & \multicolumn{2}{|c|}{ Ascorbic acid } & \multicolumn{2}{|c|}{ Inhibition (\%) } & \multicolumn{2}{|c|}{$\mathrm{IC}_{50}(\mathrm{ppm})$} \\
\hline & & $\begin{array}{l}\text { Ascorbic } \\
\text { Acid }\end{array}$ & $\begin{array}{l}\text { Bound } \\
\text { flavonoids }\end{array}$ & $\begin{array}{l}\text { Ascorbic } \\
\text { acid }\end{array}$ & $\begin{array}{l}\text { Bound } \\
\text { flavonoids }\end{array}$ & $\begin{array}{l}\text { Ascorbic } \\
\text { acid }\end{array}$ & $\begin{array}{l}\text { Bound } \\
\text { flavonoids }\end{array}$ \\
\hline \multirow{5}{*}{0.361} & 2 & 0.323 & 0.332 & 10.53 & 8.03 & \multirow{5}{*}{6.50} & \multirow{5}{*}{7.51} \\
\hline & 4 & 0.274 & 0.299 & 24.10 & 17.17 & & \\
\hline & 6 & 0.196 & 0.252 & 45.71 & 30.19 & & \\
\hline & 8 & 0.111 & 0.154 & 69.25 & 57.34 & & \\
\hline & 10 & 0.080 & 0.097 & 77.84 & 73.13 & & \\
\hline
\end{tabular}

Table 5: Effect of the bound flavonoids of B. racemosa kernel on blood glucose level of glucose-induced diabetic rats

\begin{tabular}{|c|c|c|c|c|c|}
\hline \multirow[b]{2}{*}{ Group } & \multirow[b]{2}{*}{$\begin{array}{l}\text { Dose (mg kg } \\
\text { b.wt.) }\end{array}$} & \multicolumn{4}{|c|}{ Blood glucose level (Mean \pm SD $\left.\mathrm{mg} \mathrm{dL}^{-1}\right)$} \\
\hline & & Initial & Before & After & $\begin{array}{l}\text { Antidiabetic } \\
\text { effect }(\%)\end{array}$ \\
\hline$\overline{\mathrm{NC}}$ & - & 122.67 & 402.67 & 457.67 & - \\
\hline $\mathrm{PC}$ & 65 & 129.33 & $424.67 *$ & ${ }^{\mathrm{a}} 104.00 *$ & 75.51 \\
\hline BF1 & 100 & 121.33 & $405.00 *$ & b $119.33^{*}$ & 70.53 \\
\hline BF2 & 200 & 128.67 & $408.33^{*}$ & ${ }^{\mathrm{b}} 101.33^{*}$ & 75.18 \\
\hline
\end{tabular}

NC: Negative Control, PC: Positive Control, BF1: Bound Flavonoids with a dose of $100 \mathrm{mg} \mathrm{kg}^{-1}$ b.wt., BF2: Bound Flavonoids with a dose of $200 \mathrm{mg} \mathrm{kg}^{-1}$ b.wt., b.wt.: body weight. Different letters indicated statistically significant differences $(*)$ in blood glucose level among the treatments ( $\mathrm{p}<0.05$, Duncan's post hoc following one-way ANOVA) 
Table 6: Proximal renal tubule cell scores in the rats' kidney at various treatments

\begin{tabular}{lll}
\hline Group & Dose $\left(\mathrm{mg} \mathrm{kg}^{-1}\right.$ b.wt.) & Proximal convoluted tubule score (Mean \pm SD) \\
\hline NC & - & $0.25 \pm 0.50^{\mathrm{a}}$ \\
PC & 65 & $0.50 \pm 0.57^{\mathrm{a}}$ \\
BF1 & 100 & $0.25 \pm 0.50^{\mathrm{a}}$ \\
BF2 & 200 & $0.25 \pm 0.50^{\mathrm{a}}$ \\
\hline
\end{tabular}

NC: Negative Control, PC: Positive Control, BF1: Bound Flavonoids with a dose of $100 \mathrm{mg} \mathrm{kg}^{-1}$ b.wt., BF2: Bound Flavonoids with a dose of $200 \mathrm{mg} \mathrm{kg}^{-1}$ b.wt., b.wt.: body weight. The Same letter indicated statistically insignificant differences $(F(3,15)=0.23, \mathrm{p}=$ 0.873 ) in proximal renal tubule cell count among the treatments based on one-way ANOVA analysis

Table 7: Granulation of pancreatic $\beta$-cells at various treatments

\begin{tabular}{lll}
\hline Group & Dose $\left(\mathrm{mg} \mathrm{kg}^{-1}\right.$ b.wt.) & Pancreatic $\beta$-cell (cell, Mean \pm SD) \\
\hline NC & - & $454.50 \pm 20.82^{\mathrm{a}}$ \\
PC & 65 & $384.00 \pm 30.53^{\mathrm{b}}$ \\
BF1 & 100 & $391.25 \pm 4.57^{\mathrm{b}}$ \\
BF2 & 200 & $437.00 \pm 12.05^{\mathrm{a}}$ \\
\hline
\end{tabular}

NC: Negative Control, PC: Positive Control, BF1: Bound Flavonoids with a dose of $100 \mathrm{mg} \mathrm{kg}^{-1}$ b.wt., BF2: Bound Flavonoids with a dose of $200 \mathrm{mg} \mathrm{kg}^{-1}$ b.wt., b.wt.: Body weight. Different letters indicated statistically significant differences $(F(3,15)=26.09$, p $<$ 0.0001) in pancreatic cell count among the treatments based on one-way ANOVA analysis

\section{Histopathological Study}

The histopathologic observations of the kidney and pancreas images showed results in renal damage within the normal range (Table 6) and an increase in $\beta$-cell granulation (Table 7) respectively.

\section{Discussion}

The bound flavonoids extract shown an intense red color on Shinoda's test (Raaman, 2006) based on the phytochemical analysis. In this extract, the alkaloid, phenolic, saponin, tannin and terpenoid components did not detect according to the standard procedures. This indicated that only bound flavonoids were existing in the extract. The bound flavonoids containing extract had the ability to turn deep violet color to pale yellow color in ethanolic DPPH solution. The magnitude of the reduction strength of the extract to neutralize the DPPH free radical was not much different when compared to the ability of ascorbic acid to neutralize the DPPH in terms of inhibition as shown in Table 4 . The $\mathrm{IC}_{50}$ values for the ascorbic acid and the extract were in the amount of 6.50 and $7.51 \mathrm{ppm}$ respectively based on the $\log$ inhibition curve as revealed in Fig. 1. Referring to Molyneux's (2004) that activity of an antioxidant is considered as weak, moderate, strong and very strong when the $\mathrm{IC}_{50}$ values are 150-200, 100-150, 50-100 and less than $50 \mathrm{ppm}$ respectively, therefore, the bound flavonoids extract has very strong antioxidant activity (Su et al., 2014). This fact suggested the ability of the extract to reduce free radical molecule which in this case was the DPPH. Thus, the bound flavonoids contained in the extract were thought to have the ability to neutralize the DPPH molecule which has properties as a free radical and a scavenger for other free radicals (Pavithra and Vadivukkarasi, 2015).
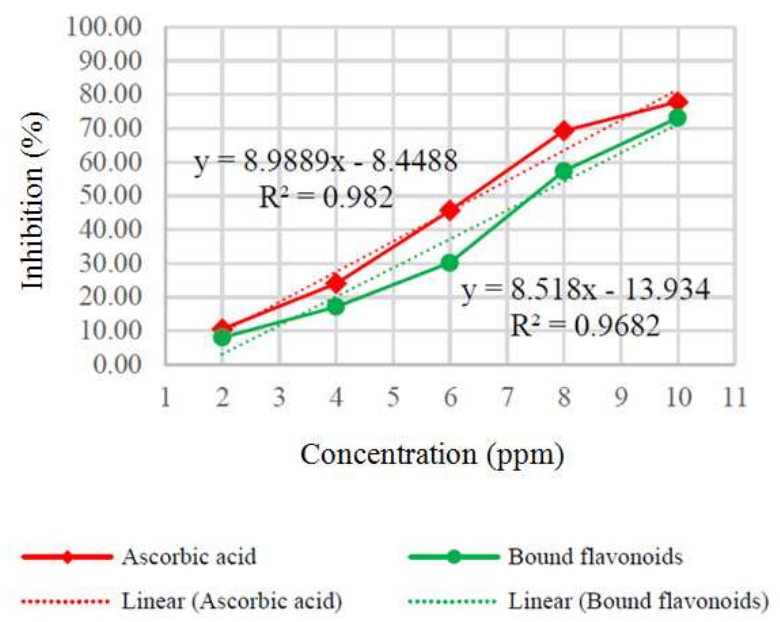

Fig. 1: Antioxidant activity of ascorbic acid and bound flavonoids at different concentrations on DPPH free radical

It was supposed that the flavonoids contained in the extract were able to work to neutralize free radicals produced through the metabolism process (Wang et al., 2013; Nimse and Pal, 2015; Elochukwu, 2015). Thus, the number of free radicals decreased and this reduced the oxidative stress which gave the pancreas an opportunity to secrete insulin into the blood. The result signposted by this fact was a reduction of blood glucose level in the glucose-induced diabetic rats (Bajaj and Khan, 2012; King, 2012; Czompa et al., 2017). In terms of one-way ANOVA results, there was a significant difference $(p<0.05)$ among groups in response to antioxidants given to the tested rats. Indeed, the magnitude of the antidiabetic effect of the metformin (75.51\%) and the extract (70.53 and $75.18 \%$ for BF1 and BF2 respectively) showed a very small difference in numbers as displayed in Table 5. This indicated that the 
bound flavonoids contained in the extract were thought to be able to reduce blood glucose level as well as the metformin as revealed in Fig. 2.

Renal histopathologic observational data were described in semi-quantitative descriptive and scores with a scale of 0 to 2 (Suhita et al., 2013). The mark 0 states no lesions in the organ. The mark 1 suggests hydropic degeneration, fatty degeneration, karyomegaly and pycnosis. The mark 2 states the occurrence of necrosa. Each individual score was then counted up and the mean of the group was determined for comparison with controls, then, a mild (score 0), moderate (score 1) and severe (score 2) lesions were identified and described.

The renal histopathologic observation was performed on proximal tubule nuclei as revealed in Table 6 . The kidney is a target organ of insulin. Insulin binds to the insulin receptors via the nephron (Nakamura et al., 1983), which is essential for the proper function of the nephron, glomerulus and tubule (Hale and Coward, 2013). In insulin resistance, the insulin signaling cascade in the glomerulus seems to be impaired (Lay and Coward, 2014). In diabetic conditions, insulin stimulation in the transportation of proximal renal tubules is impaired so that glucose reabsorption decreases and glucose is excreted through urine (Horita et al., 2017). The administration of the bound flavonoids extract improved the kidney and the visible cells in the proximal tubule were the same as a normal rat (Fig. 3).

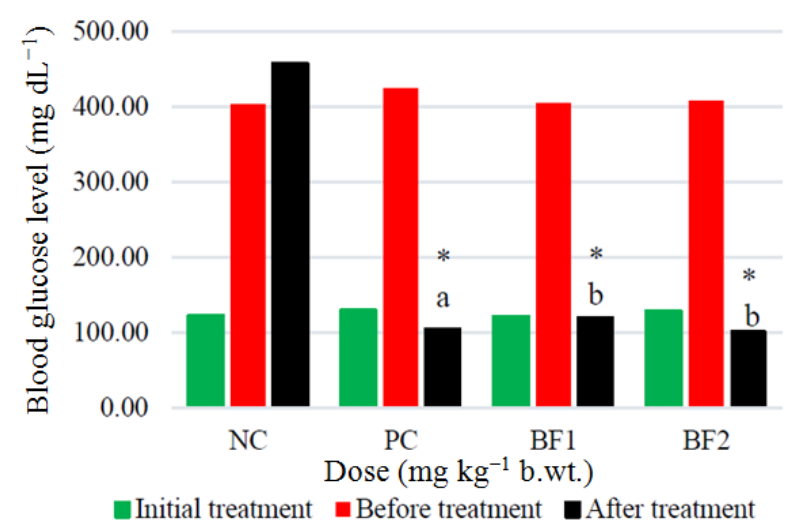

Fig. 2: Blood glucose level of tested rats detected at initial, before and after treatments in the normal rat $(\mathrm{NC})$, metformin (PC), diabetic rat + bound flavonoids extract with a dose of $100 \mathrm{mg} \mathrm{kg}^{-1}$ b.wt. (BF1), diabetic rat + bound flavonoids extract with a dose of $200 \mathrm{mg} \mathrm{kg}^{-1}$ b.wt. (BF2). b.wt.: body weight. The asterisk with different letters indicated a statistically significant difference $(p<0.05)$ based on one-way ANOVA analysis
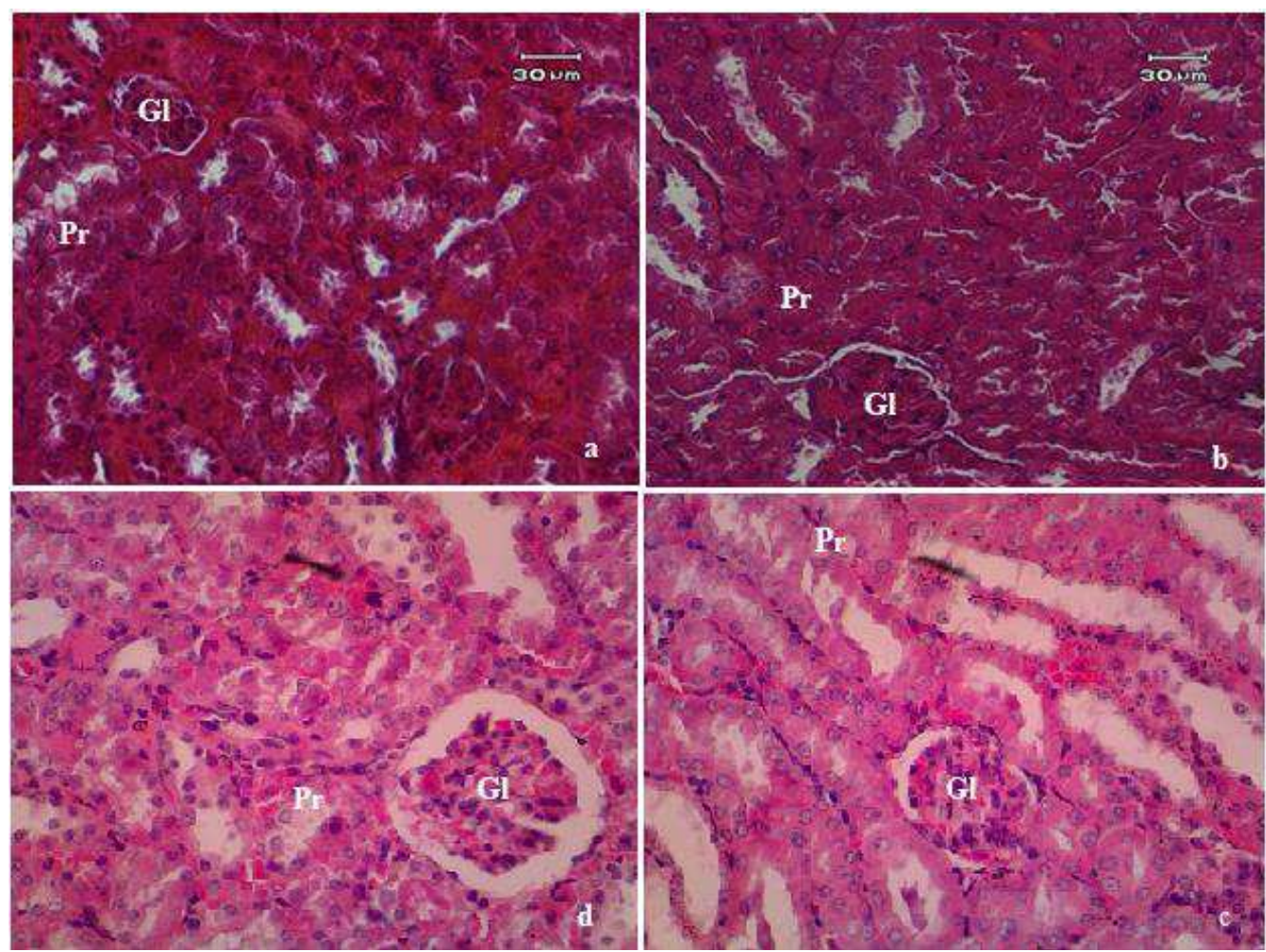

Fig. 3: Histopathological performance of kidney in the normal rat (a), metformin (b), diabetic rat + bound flavonoid extract with a dose of $100 \mathrm{mg} \mathrm{kg}^{-1}$ b.wt. (c), diabetic rat + bound flavonoids extract with a dose of $200 \mathrm{mg} \mathrm{kg}^{-1}$ b.wt. (d). Pr: Proximal convoluted tubule, Gl: Glomerulus, b.wt.: body weight 

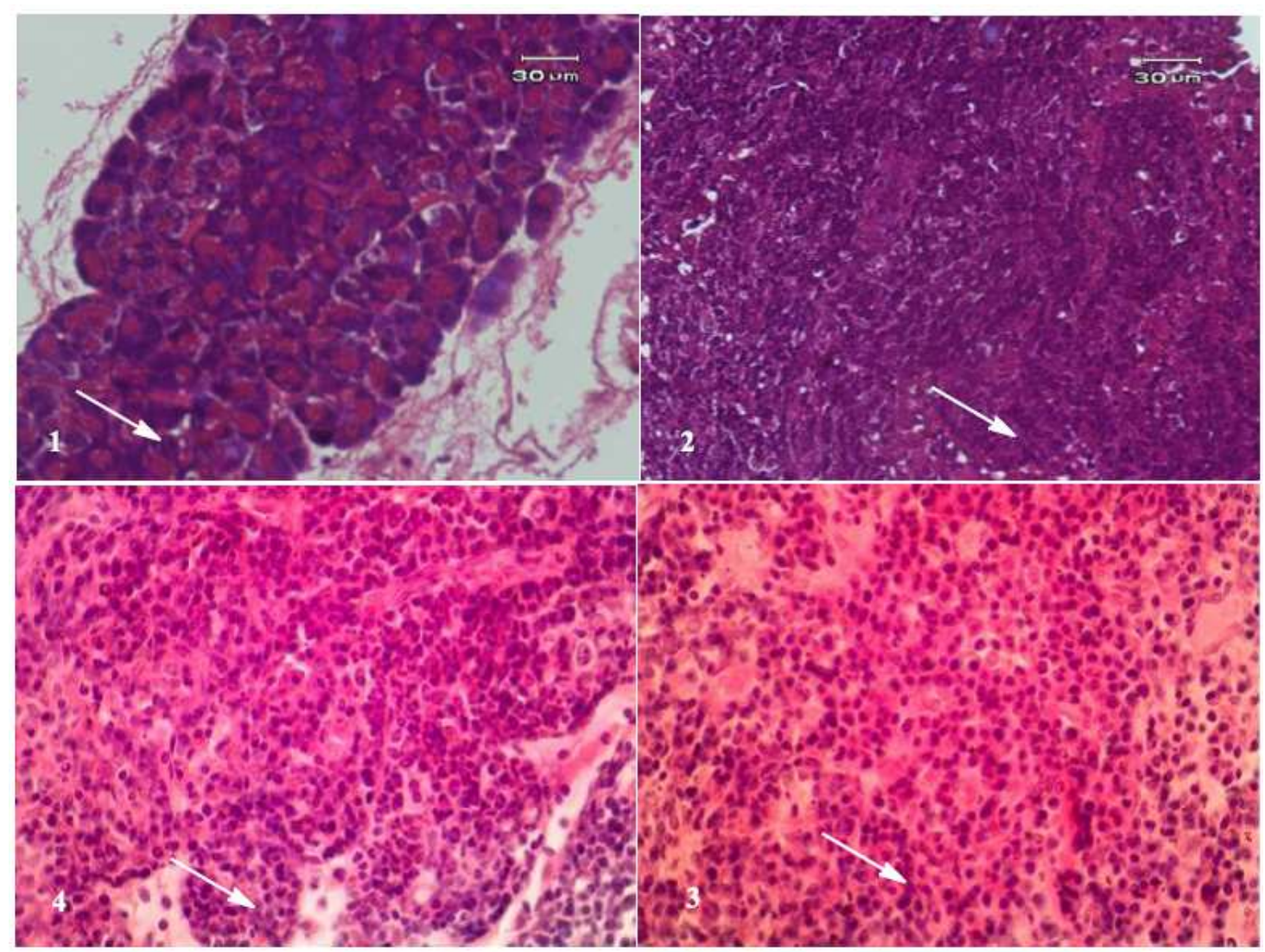

Fig. 4: Histopathological observation of pancreatic $\beta$-cell as indicated by the white arrow in the normal rat (1), metformin (2), diabetic rat + bound flavonoids extract with a dose of $100 \mathrm{mg} \mathrm{kg}^{-1}$ b.wt. (3), diabetic rat + bound flavonoids extract with a dose of $200 \mathrm{mg} \mathrm{kg}^{-1}$ b.wt. (4). b.wt.: body weight

The score value of renal proximal tubule cells in diabetic rats given metformin by 0.50 expressed damage conditions in the normal range as shown in Fig. 3. The metformin could reduce hyperglycemia in the blood so it could reduce damage to proximal renal tubular cells. The one-way ANOVA results showed that the bound flavonoid extract given to diabetic rats did not cause any significant change in the histologic structure of the kidney $(F(3,15)=0.23, \mathrm{p}=0.873)$. Indeed, the result of scores on a proximal tubular cell in diabetic rats given the extract displayed 0.25 . This result indicated that the physiological functions of renal cells worked within the range of normal changes (Khoshnoud et al., 2017). This suggested that administration of the bound flavonoids extract of $B$. racemosa kernel in diabetic rats did not show specific damage to proximal renal tubular cells. Thus, the bound flavonoids contained in the extract did not cause damage to the kidney organs in the tested rats when applied as a controlling agent for type 2 diabetes.

The histopathologic images demonstrated that the pancreatic $\beta$-cell granulation was directly proportional to the given extract dose as shown in Table 7 . The number of $\beta$-cells enhancement $(F(3,15)=26.09, \mathrm{p}<0.0001)$ for each treatment stated that the bound flavonoids extract administered to hyperglycemic rats could improve pancreatic $\beta$-cells and depresses necrosis or apoptosis of pancreatic $\beta$-cells compared to metformin as shown in Figure 4. It was assumed that the modulatory effects of bound flavonoid constituents on the blood glucose transporter by increasing insulin secretion, decreasing apoptosis and stimulating proliferation of pancreatic $\beta$-cells (Fu et al., 2012; Vinayagam and $\mathrm{Xu}, 2015$; Zheng et al., 2016).

\section{Conclusion}

The bound flavonoids extract of $B$. racemosa kernel showed the strong antioxidant power and it displayed the type 2 anti-diabetes property. Administration of the extract with doses of $100 \mathrm{mg}$ $\mathrm{kg}^{-1}$ b.wt. and $200 \mathrm{mg} \mathrm{kg}^{-1}$ b.wt. orally for 14 days was not causing the histopathologic disturbance on the tested rat kidney organ.

\section{Acknowledgement}

Authors are thankful to Prof. Dr. Djufri, M.Si., the plant taxonomist of Teacher Teaching and Education 
Faculty of Syiah Kuala University, for identification and authentication of Barringtonia racemosa (L.) Spreng.

\section{Research Funding}

The research was supported by Syiah Kuala University funding (grant number: 33/UN11.2/PP/PNBP/SP3/2017).

\section{Conflict of Interest}

The authors declare that they do not have any conflict of interests.

\section{Author's Contribution}

Musri Musman: Conceived, designed the experiments and wrote the paper.

Emelda Audina: Performed the experiments.

Fazlia I. R. Ratu: Experimental tools analyses.

Erlidawati Erlidawati: Provided reagents and materials.

Safrida Safrida: Analyzed the data.

\section{Ethics}

This original article contains unpublish material. The corresponding author states that all of the other authors have read and agreed to the manuscript and no ethical issues are involved.

\section{References}

Abdul-Ghani, M. and R. DeFronzo, 2010. Pathogenesis of insulin resistance in skeletal muscle. J. Biomed. Biotechnol., 2010: 1-19. DOI: 10.1155/2010/476279

Adewunmi, C.O., A.J. Aladesanmi, F.B. Adewoyin, J.A.O. Ojewole and N. Naido, 2001. Molluscicidal, insecticidal and piscicidal activities of Barringtonia racemosa. Nig. J. Nat. Prod. Med., 5: 56-58. DOI: $10.4314 /$ NJNPM.V5I1.11727

Alexandru, I., 2011. Experimental use of animal in research spa. Balneo Res. J., 2: 65-69. DOI: $10.12680 /$ balneo.2011.1014

ADA, 2015. Classification and diagnosis of diabetes. Diabetes Care, 38: 58-516. DOI: 10.2337/dc15-S005

Amić, D., D. Davidović-Amić, D. Bešlo and N. Trinajstić, 2003. Structure-radical scavenging activity relationship of flavonoids. Croatia Chem. Acta, 76: 55-61.

Amran, N., A.N.A. Rani, R. Mahmud and K.B. Yin, 2016. Antioxidant and cytotoxic effect of Barringtonia racemosa and Hibiscus sabdariffa fruit extracts in MCF-7 human breast cancer cell line. Pharmacognosy Res., 8: 66-70. DOI: $10.4103 / 0974-8490.171104$
Arul, B., R. Kothai and A.J.M. Christina, 2006. Antihyperglycemic and hypoglycemic effect of Bougainvillea spectabilis Linn. In normal and glucoseinduced diabetic rats. Hamdard Med., 49: 18-21.

Babu, P.V.A., D. Liu and E.R. Gilbert, 2013. Recent advances in understanding the anti-diabetic actions of dietary flavonoids. J. Nutr. Biochem., 24: 1777-1789. DOI: 10.1016/j.jnutbio.2013.06.003

Bagchi, K. and S. Puri, 1998. Free radicals and antioxidants in health and disease. East Mediterranean Health Jr., 4: 350-60.

Bajaj, S. and A. Khan, 2012. Antioxidants and diabetes. Ind. J. Endocrinol Metab., 16: S267-S271. DOI: $10.4103 / 2230-8210.104057$

Bansal, A.K. and G.S. Bilaspuri, 2011. Impacts of oxidative stress and antioxidants on semen functions. Vet. Med. Int. 2011: 686137-686137. DOI: $10.4061 / 2011 / 686137$

Banu, K.S. and L. Cathrine, 2015. General techniques involved in phytochemical analysis. IJARCS, 2: 25-32.

Behbahani, M., A.M. Ali, R. Muse and N.B. Mohammad, 2007. Anti-oxidant and antiinflammatory activities of leaves of Barringtonia racemosa. J. Med. Plants Res., 1: 95-102.

Betteridge, D.J., 2000. What is oxidative stress? Metabolism, 49: 3-8. PMID: 10693912

Brownlee, M., 2001. Biochemistry and molecular cell biology of diabetic complications. Nature, 414: 813-20. PMID: 11742414

Candasamy, M., T.E.G.K. Murthy, K.S. Gubiyappa, D.K. Chellappan and G. Gupta, 2014. Alteration of glucose lowering effect of glibenclamide on single and multiple treatments with fenofibrate in experimental rats and rabbit models. J. Basic Clin. Pharmacy, 5: 62-67.

DOI: $10.4103 / 0976-0105.139728$

Ceriello, A. and E. Motz, 2004. Is oxidative stress the pathogenic mechanism underlying insulin resistance, diabetes and cardiovascular disease? The common soil hypothesis revisited. Arterioscler Thromb Vasc Biol., 24: 816-23. DOI: 10.1161/01.ATV.0000122852.22604.78

Chan, E.W.C., S. Baba, H.T. Chan, M. Kainuma and T. Inoue et al., 2017. Ulam herbs: A review on the medicinal properties of Anacardium occidentale and Barringtonia racemosa. J. Applied Pharmaceutical Sci., 7: 241-247. DOI: 10.7324/JAPS.2017.70235

Chikezie, P.C., O.A. Ojiako and A.C. Ogbuji, 2015. Oxidative stress in diabetes mellitus. Integr Obesity Diabetes. DOI: 10.15761/IOD.1000116

Czompa, A., A. Gyongyosi, K. Szoke, I. Bak and E. Csepanyi et al., 2017. Effects of Momordica charantia (Bitter Melon) on ischemic diabetic myocardium. Molecules, 22: 488-502.

DOI: $10.3390 /$ molecules22030488 
Dalila, Z.D., J. Hafsah and A.A. Manaf, 2015. Antioxidant properties and total phenolic content in different development stages of Barringtonia racemosa and Barringtonia spicata leaves. Walailak J. Sci. Technol., 12: 449-458. http://wjst.wu.ac.th/index.php/wjst/issue/view/38

Das, S. and J.P.N. Rosazza, 2006. Microbial and enzymatic transformations of flavonoids. J. Nat. Prod., 69: 499-508. DOI: 10.1021/np0504659

Das, S.K., D. Samantaray, J.K. Patra, L. Samanta and H. Thatoi, 2016. Antidiabetic potential of mangrove plants: A review. Frontiers Life Sci., 9: 75-88. DOI: $10.1080 / 21553769.2015 .1091386$

Deraniyagala, S.A., W.D. Ratnasooriya and C.L. Goonasekera, 2003. Antinociceptive effect and toxicological study of the aqueous bark extract of Barringtonia racemosa on rats. J. Ethnopharmacol., 86: 21-26. PMID: 12686437

Devasagayam, T.P., J.C. Tilak, K.K. Boloor, K.S. Sane and S.S. Ghaskadbi et al., 2004. Free radicals and antioxidants in human health: Current status and future prospects. J Assoc. Phys. India, 52: 794-804. PMID: 15909857

Dewanjee, S., A. Maiti, R. Sahu, T.K. Dua and V. Mandal, 2011. Effective control of type 2 diabetes through antioxidant defense by edible fruits of Diospyros peregrine. Evidence-Based Complementary Alternative Med., 2011: 675397-675397.

DOI: $10.1093 /$ ecam/nep080

Elochukwu, C., 2015. Generation and reaction of free radicals in the human body: A major cause of aging and chronic degenerative diseases. EC Nutr., 1: 132-136.

Evans, W.C., 2009. Trease and Evans' Pharmacognosy. 16th Edn., Saunders Elsevier, India, ISBN-13: 978-0-7020-2934-9, pp: 585.

Fawcett, A., 2012. Guidelines for the housing of mice in scientific institutions. ARRP Guideline 22, Animal Welfare Unit, NSW Department of Primary Industries, NSW.

Ferreyra, M.L.F., S.P. Rius and P. Casati, 2012. Flavonoids: Biosynthesis, biological functions and biotechnological applications. Frontiers Plant Sci., 3: 1-15. DOI: 10.3389/fpls.2012.00222

Fu, Z., E.R. Gilbert, L. Pfeiffer, Y. Zhang and Y. Fu et al., 2012. Genistein ameliorates hyperglycemia in a mouse model of nongenetic type 2 diabetes. Applied Physiol. Nutr. Metabolism, 37: 480-488. DOI: $10.1139 / \mathrm{h} 2012-005$

Ganesan, K., S.K.P. Nair, M. Sinaga and S.B. Gani, 2016. A review on the phytoconstituents and pharmacological actions in the medicinal plants of Bedabuna forest, Jimma zone, South West Ethiopia reported effect on experimental models. World J. Biomed. Pharmaceutical Sci., 3: 62-83.
Giesen, W., S. Wulfraat, M. Zieren and L. Scholten, 2007. Barringtonia Racemosa. In: Mangrove Guidebook for Southeast Asia, FAO and Wetlands International, Bangkok, Thailand and Wageningen, Netherlands, ISBN-13: 974-7946-85-8.

Gowri, P.M., A.K. Tiwari, A.Z. Ali and J.M. Rao, 2007. Inhibition of $\alpha$-glucosidase and amylase by bartogenic acid isolated from Barringtonia racemosa Robx. seeds. Phytotherapy Res., 21: 796-799. DOI: $10.1002 /$ ptr.2176

Gowri, P.M., S.V. Radhakrishnan, S.J. Basha, A.V. Sarma and J.M. Rao, 2009. Oleanane-type isomeric triterpenoids from Barringtonia racemosa. J. Nat. Prod., 72: 791-795. DOI: 10.1021/np8007396

Hahlbrock, K., 1981. FLAVONOIDS. In: Secondary Plant Products, Stumpf, P.K. and E.E. Conn (Eds.), Academic Press, New York, ISBN-13: 9781483289229, pp: 425-456.

Hale, L.J. and R.J. Coward, 2013. The insulin receptor and the kidney. Curr. Opin. Nephrol. Hypertens., 22: 100-106. DOI: 10.1097/MNH.0b013e32835abb52

Halliwell, B., 1995. How to characterize an antioxidantan update. Biochem. Soc. Symp., 61: 73-101. PMID: 8660405

Harborne, A.J., 1998. Phytochemical Methods a Guide to Modern Techniques of Plant Analysis. 3rd Edn., Springer Netherlands, Netherlands, ISBN-13: 978-0412-57260-9, pp: 302.

Hasan, C.M., S. Khan, A. Jabbar and M.A. Rashid, 2000. Nasimaluns A and B: Neo-clerodane diterpenoids from Barringtonia racemosa. J. Nat. Prod., 63: 410-411. DOI: $10.1021 / \mathrm{np} 9904881$

Heim, K.E., A.R. Tagliaferro and D.J. Bobilya, 2002. Flavonoid antioxidants: Chemistry, metabolism and structure-activity relationships. J. Nutrit. Biochem., 13: 572-584. PMID: 12550068

Horita, S., M. Nakamura, M. Suzuki, N. Satoh and A. Suzuki et al., 2017. The role of renal proximal tubule transport in the regulation of blood pressure. Kidney Res. Clint Pract., 36: 12-21. DOI: $10.23876 /$ j.krcp.2017.36.1.12

Hossain, M.S., M.S. Rahman, A.H.M.R. Imon, S. Zaman and A.S.M.B.A. Siddiky et al., 2016. Ethnopharmacological investigations of methanolic extract of Pouzolzia zeylanica (L.) Benn. Clin. Phytosci., 2: 10-19. DOI: 10.1186/s40816-016-0022-7

Huang, D.J., B.X. Ou and R.L. Prior, 2005. The chemistry behind antioxidant capacity assays. J. Agric. Food Chem., 53: 1841-1856. DOI: 10.1021/jf030723c

Hussin, N.M., R. Muse, S. Ahmad, J. Ramli and M. Mahmood et al., 2009. Antifungal activity of extracts and phenolic compounds from Barringtonia racemosa L. (Lecythidaceae). Afr. J. Biotechnol., 8: 2835-2842. DOI: $10.5897 / A J B 09.450$ 
Iqbal, Z., A. Ashraf, A. Touseef, F. Farman and A. Asghar et al., 2016. Antioxidant activity of essential oil of mature bulbof Allium cepa L. from Pakistan. World J. Pharmaceutical Res., 5: 1959-1965. DOI: 10.20959/wjpr20166-6378

Jakus, V., 2000. The role of free radicals, oxidative stress and antioxidant systems in diabetic vascular disease. Bratisl Lek Listy, 101: 541-51. PMID: 11218944

Jayaweera, D.M.A., 1981. Medicinal plants (indigenous and exotic) used in Ceylon, part III. The National Science Council of Sri Lanka, Colombo.

Kabir, M.Z., S.M. Rahman, M.R. Islam, P.K. Paul and S. Rahman et al., 2013. A review on a mangrove species from the Sunderbans, Bangladesh: Barringtonia racemosa (L.) roxb. Am. Eurasian J. Sustainable Agric., 7: 356-372.

Kamalakkannan, N. and P.S. Prince, 2006. Antihyperglycaemic and antioxidant effect of rutin, a polyphenolic flavonoid, in streptozotocin-induced diabetic wistar rats. Basic Clin. Pharmacol. Toxicol., 98: 97-103. DOI: $10.1111 /$ j.1742-7843.2006.pto_241.X

Kan, E., E. Kiliçkan, A. Ayar and R. Colak, 2015. Effects of two antioxidants; $\alpha$-lipoic acid and fisetin against diabetic cataract in mice. Int Ophthalmol., 35: 115-120. DOI: 10.1007/s10792-014-0029-3

Kangralkar, V.A., S.D. Patil and R.M. Bandivadekar, 2012. Oxidative stress and diabetes: A review. Int. J. Pharma Appl., 1: 38-45.

Khan, S., A. Jabbar, C.M. Hasan and M.A. Rashid, 2001. Antibacterial activity of Barringtonia racemosa. Fitoterapia, 72: 162-164.

DOI: $10.1016 / \mathrm{S} 0367-326 \mathrm{X}(00) 00264-1$

Khoshnoud, S., H.M. Kouchesfahani and M. Nabiuni, 2017. Evaluation of the protective effect of hydroalcoholic extract of raspberry fruit on aquaporin 1 expression in rats kidney treated by methotrexate. Cell J., 19: 306-313. DOI: 10.22074/cellj.2016.3957

King, A.J.F., 2012. The use of animal models in diabetes research. Br J. Pharmacol., 166: 877-894. DOI: 10.1111/j.1476-5381.2012.01911.x

Kong, K.W., S. Mat-Junit, N. Aminudin, F.A. Hassan and A. Ismail et al., 2016a. Protective effects of the extracts of Barringtonia racemosa shoots against oxidative damage in HepG2 cells. Peer J., 4: e1628-e1628. DOI: 10.7717/peerj.1628

Kong, K.W., A. Abdul-Aziz, N. Razali, N. Aminuddin and S. Mat-Junit, 2016b. Antioxidant-rich leaf extract of Barringtonia racemosa significantly alters the in vitro expression of genes encoding enzymes that are involved in methylglyoxal degradation III. Peer J., 4: e2379-e2379. DOI: 10.7717/peerj.2379

Kong, K.W., S. Mat-Junit, A. Ismail, N. Aminudin and A. Abdul-Aziz, 2014. Polyphenols in Barringtonia racemosa and their protection against oxidation of LDL, serum and haemoglobin. Food Chem., 146: 85-93. DOI: 10.1016/j.foodchem.2013.09.012
Kong, K.W., S. Mat-Junit, N. Aminudin, A. Ismail and A. Abdul-Aziz, 2012. Antioxidant activities and polyphenolics from the shoots of Barringtonia racemosa (L.) Spreng in a polar to apolar medium system. Food Chem., 134: 324-332.

DOI: 10.1016/j.foodchem.2012.02.150

Kumar, S. and A.K. Pandey, 2013. Chemistry and biological activities of flavonoids: An overview. Scientific World J., 2013: 162750-162750. DOI: $10.1155 / 2013 / 162750$

Laight, D.W., M.J. Carrier and E.E. Anggard, 2000. Antioxidants, diabetes and endothelial dysfunction. Cardiovasc. Res., 47: 457-64. PMID: 10963719

Lay, A. and R.J. Coward, 2014. Recent advances in our understanding of insulin signaling to the podocyte. Nephrol. Dial Transplant. 29: 1127-1133.

DOI: $10.1093 / \mathrm{ndt} / \mathrm{gft} 471$

Li, J., F. Gong and F. Li, 2016. Hypoglycemic and hypolipidemic effects of flavonoids from tatary buckwheat in type 2 diabetic rats. Biomed. Res., 27: 132-137.

Lim, T.K., 2012. Barringtonia racemosa. In: Edible Medicinal and Non-Medicinal Plants, Lim T.K. (Ed.), Springer Science and Business Media BV, Dordrecht, Heidelberg, London and New York, ISBN-13: 978-94-007-2534-8, pp: 114-121.

Lobo, V., A. Patil, A. Phatak and N. Chandra, 2010. Free radicals, antioxidants and functional foods: Impact on human health. Pharmacogn. Rev., 4: 118-126. DOI: $10.4103 / 0973-7847.70902$

Mackeen, M.M., A.M. Ali, S.H. El-Sharkawi, M.Y. Manap and K.M. Salleh et al., 1997. Antimicrobial and cytotoxic properties of some Malaysian traditional vegetables (Ulam). Int. J. Pharmacog., 35: 174-178. DOI: 10.1076/phbi.35.3.174.13294

Maddux, B.A., W. See, J.C. Lawrence, Jr., A.L. Goldfine and I.D. Goldfine et al., 2001. Protection against oxidative stress-induced insulin resistance in rat L6 muscle cells by micromolar concentrations of alpha-lipoic acid. Diabetes, 50: 404-10.

Manjunath, B.L., 1948. The Wealth of India: A Dictionary of Indian Raw Materials and Industrial Products. 1st Edn., Council of Scientific and Industrial Research, New Delhi, ISBN-10: 8185038-00-7, pp: 159.

Martin, A.C., R.A. Sanders and J.B. Watkins, 2003. Diabetes, oxidative stress and antioxidants: A review. J. Biochem. Mol. Toxicol., 17: 24-38. DOI: $10.1002 / \mathrm{jbt} .10058$

Mmushi, T.J., P. Masoko, L.K. Mdee, M.P. Mokgotho and L.J. Mampuru et al., 2010. Anti-mycobacterial evaluation of fifteen medicinal plants in South Africa. Afr. J. Tradit. Complement Altern. Med., 7: 34-39.

Molyneux, P., 2004. The use of the stable free radical Diphenylpicrylhydrazyl (DPPH) for estimating antioxidant activity. Songklanakarin J. Sci. Technol., 26: 211-219. 
Montonen, J., P. Knekt, R. Jarvinen and A. Reunanen, 2004. Dietary antioxidant intake and risk of type 2 diabetes. Diabetes Care, 27: 362-366.

PMID: 14747214

Musman, M., 2010. Toxicity of Barringtonia racemosa (L.) Kernel extract on Pomacea canaliculata (Ampullariidae). Tropical Life Sci. Res., 21: 41-50.

Musman, M., S. Kamaruzzaman, S. Karina, R. Rizqi and F. Arisca, 2013. A preliminary study on the antihatching of freshwater golden apple snail Pomacea canaliculata (Gastropoda: Ampullariidae) eggs from Barringtonia racemosa (Magnoliopsida: Lecythidaceae) seeds extract. AACL Bioflux, 6: 394-398.

Musman, M., S. Karina and F. Rizki, 2014. Saponins extract from Barringtonia racemosa as molluscicide to brackishwater pond snails (Cerithidea cingulata). Int. J. Applied Res. Technol., 3: 92-97.

Musman, M., S. Karina, C.N. Defira, N. Fadhillah and A. Kayana et al., 2015. Phytofungitoxic agent from wild plants. IJSBAR, 21: 78-85.

Nadkarni, A.K., 1976. Dr. KM Nadakarni's Indian Materia Medica. 3rd Ed., Popular Prakashan Ltd., Bombay, pp: 177.

Nakamura, R., D.S. Emmanuel and A.I. Katz, 1983. Insulin binding sites in various segments of the rabbit nephron. J. Clin. Invest., 72: 388-392.

DOI: $10.1172 /$ JCI110979

Nazaruk, J. and M. Borzym-Kluczyk, 2015. The role of triterpenes in the management of diabetes mellitus and its complications. Phytochem. Rev., 14: 675-690. DOI: $10.1007 / \mathrm{s} 11101-014-9369-\mathrm{x}$

Nijveldt, R.J., E. van Nood, D.E.C. van Hoorn, P.G. Boelens and K. van Norren et al., 2001. Flavonoids: A review of probable mechanisms of action and potential application. Am. J. Clin. Nutr., 74: 418-25. PMID: 11566638

Nimse, S.B. and D.K. Pal, 2015. Free radicals, natural antioxidants and their reaction mechanisms. R. Society Chem. Adv., 5: 27986-28006. DOI: $10.1039 / \mathrm{C} 4 \mathrm{RA} 13315 \mathrm{C}$

Nurul-Mariam, H., M. Radzali, R. Johari, A. Syahida and M. Maziah, 2008. Antioxidant activities of different aerial parts of Putat (Barringtonia racemosa L.). Malaysian J. Biochem. Mol. Biol., 16: 15-24.

Ojewole, J.A.O., N. Nundkumar and C.O. Adewunmi, 2004. Molluscicidal, cercariacidal, larvacidal and antiplasmodial properties of Barringtonia racemosa fruit and seed extracts. BLACPMA, 3: 88-92.

Osman, N.I., N.J. Sidik and A. Awal, 2015. Pharmacological activities of Barringtonia racemosa L. (Putat), a tropical medicinal plant species. J. Pharm. Sci. Res., 7: 185-188.
Osman, N.I., N.J. Sidik, A. Awal, N.A.M. Adam and N.I. Rezali, 2016. In vitro xanthine oxidase and albumin denaturation inhibition assay of Barringtonia racemosa $\mathrm{L}$. and total phenolic content analysis for potential anti-inflammatory use in gouty arthritis. J. Intercult. Ethnopharmacol., 5: 343-349. DOI: $10.5455 /$ jice. 20160731025522

Pandey, K.B. and S.I. Rizvi, 2009. Plant polyphenols as dietary antioxidants in human health and disease. Oxid. Med. Cell Longev., 2: 270-278.

DOI: 10.4161/oxim.2.5.9498

Pandeya, K.B., I.P. Tripathi, M.K. Mishra, N. Dwivedi and Y. Pardhi et al., 2013. A critical review on traditional herbal drugs: An emerging alternative drug for diabetes. Int. J. Organic Chem., 3: 1-22. DOI: 10.4236/ijoc.2013.31001

Patil, K.R. and C.R. Patil, 2016. Anti-inflammatory activity of bartogenic acid containing fraction of fruits of Barringtonia racemosa Roxb. In acute and chronic animal models of inflammation. J. Tradit. Complementary Med., 7: 86-93. DOI: 10.1016/j.jtcme.2016.02.001

Patil, K.R., C.R. Patil, R.B. Jadhav, V.K. Mahajan and P. Raosaheb et al., 2011. Anti-arthritic activity of bartogenic acid isolated from fruits of Barringtonia racemosa Roxb. (Lecythidaceae). Evidence-Based Complementary Alternative Med., 2011: 1-7. DOI: $10.1093 /$ ecam/nep148

Patil, P.R., M.R. Patil, A. Mane and S. Patil, 2013. Immunomodulatory effects of fruits of Barringtonia racemosa Linn. Int. J. Basic Clin. Pharmacol., 2: 216-219. DOI: 10.5455/2319-2003.ijbcp20130318

Patil, S., M.R. Patil, P. Patil, R. Dixit and R.C. Sharma, 2014. Effects of fruits of Barringtonia racemosa linn. on human polymorphonuclear cell. Int. J. Anat. Res., 2: 806-809. DOI: 10.16965/ijar.2014.553

Pavithra, K. and S. Vadivukkarasi, 2015. Evaluation of free radical scavenging activity of various extracts of leaves from Kedrostis foetidissima (Jacq.) Cogn. Food Sci. Human Wellness, 4: 42-46. DOI: $10.1016 /$ j.fshw.2015.02.001

Pham-Huy, L.A., H. He and C. Pham-Huy, 2008. Free radicals, antioxidants in disease and health. IJBS, 4: 89-96.

Pietta, P.G., 2000. Flavonoids as antioxidants. J. Nat Prod., 63: 1035-42. PMID: 10924197

Ponnapalli, M.G., S. Sukki, S.C.V.A.R. Annam, M. Ankireddy and H. Tirunagari et al., 2015. $\alpha$-Glucosidase inhibitory monoacylated polyhydroxytriterpenoids from the fruits of Barringtonia racemosa. Tetrahedron Lett., 56: 1570-1574. DOI: 10.1016/j.tetlet.2015.01.193 
Raaman, N., 2006. Phytochemical Techniques. 1st Edn., New Indian Publishing Agency, New Delhi, ISBN10: 8189422308 , pp: 318 .

Rice-Evans, C.A., N.J. Miller and G. Paganga, 1996. Structure-antioxidant activity relationships of flavonoids and phenolic acids. Free Rad. Biol. Med., 20: 933-956. PMID: 8743980

Rice-Evans, C., 2001. Flavonoid antioxidants. Curr. Med. Chem., 8: 797-807. PMID: 11375750

Rice-Evans, C., N. Miller and G. Paganga, 1997. Antioxidant properties of phenolic compounds. Trends Plant Sci., 2: 152-159.

DOI: $10.1016 / \mathrm{S} 1360-1385(97) 01018-2$

RIRDC, 2017. Listing of interesting plants of the world: Barringtonia racemosa. Australian New Crops Info 2016, Rural Industries Research and Development Corporation.

Saha, S., K.K. Sarkar, M.L. Hossain, A. Hossin and A.K. Barman et al., 2013. Bioactivity studies on Barringtonia racemosa (lam.) Bark. Pharmacol. OnLine, 1: 93-100.

Samanta, S.K., K. Bhattacharya, C. Mandal and B.C. $\mathrm{Pal}, 2010$. Identification and quantification of the active component quercetin 3-O-rutinoside from Barringtonia racemosa targets mitochondrial apoptotic pathway in acute lymphoblastic leukemia. J. Asian Nat. Prod. Res., 12: 639-648. DOI: $10.1080 / 10286020.2010 .489040$

Sangeetha, V.S., M. Babu and B. Lawrence, 2014. Phytochemical analysis of Annona reticulata L. leaf extracts. Int. Res. J. Pharm. Applied Sci., 4: 4-8.

Santos-Buelga, C. and A.S. Feliciano, 2017. Flavonoids: From structure to health issues. Molecules, 22: 477-482. DOI: $10.3390 /$ molecules22030477

Sikha, P., P.G. Latha, S.R. Suja, G.I. Anuja and S. Shyamal et al., 2010. Anti-inflammatory and analgesic activity of Barringtonia racemosa Roxb. Fruits. Ind. J. Nat. Prod. Resour., 1: 356-361.

Spitalnik, P.F., 2016. Histology laboratory manual 20162017. College of Physicians and Surgeons, Columbia University, New York.

Steel, R.G.D., J.H. Torrie and D.A. Dickey, 1997. Principles and Procedures of Statistics: A Biometrical Approach. 3rd Edn., McGraw-Hill, New York, ISBN-10: 0070610282, pp: 666.

Su, D., R. Zhang, F. Hou, M. Zhang and J. Guo et al., 2014. Comparison of the free and bound phenolic profiles and cellular antioxidants of litchi pulp extracts from different solvents. BMC Complement Altern. Med., 14: 9-9. DOI: $10.1186 / 1472-6882-14-9$

Subramanian, S.S. and S. Nagarajan, 1969. Flavonoids of the seeds of Crotolaria retusa and C.striata. Curr. Sci., 38: 65-68.
Suhita, N.L. P.R., I.W. Sudira and I.B.O. Winaya, 2013. Histopathological kidney of rat white the effect of the pegagan (Centella asiatica) extract against peroral. Buletin Veteriner Udayana, 5: 71-78.

Sulaiman, S.F. and K.L. Ooi, 2014. Antioxidant and $\alpha-$ glucosidase inhibitory activities of 40 tropical juices from Malaysia and identification of phenolics from the bioactive fruit juices of Barringtonia racemosa and Phyllanthus acidus. J. Agric. Food Chem., 62: 9576-9585. DOI: $10.1021 /$ jf502912t

Sun, H.Y., L.J. Long and J. Wu, 2006. Chemical constituents of mangrove plant Barringtonia racemosa. Zhong Yao Cai, 29: 671-672. PMID: 17059003

Tachibana, Y., A. Kato, Y. Nishiyama, M. Ikemi and K. Ohoka et al., 1996. Mitogenic activity in African traditional herbal medicines (Part II). Phytomedicine, 2: 335-339.

DOI: 10.1016/S0944-7113(96)80078-X

Thomas, T.J., B. Panikkar, A. Subramanian, M.K. Nair and K.R. Panikkar, 2002. Antitumour property and toxicity of Barringtonia racemosa Roxb seed extract in mice. J. Ethnopharmacol., 82: 223-227. DOI: $10.1016 / \mathrm{S} 0378-8741(02) 00074-0$

Ullah, A., A. Khan and I. Khan, 2016. Diabetes mellitus and oxidative stress-A concise review. Saudi Pharmaceutical J., 24: 547-553. DOI: $10.1016 /$ j.jsps.2015.03.013

Vinayagam, R. and B. Xu, 2015. Antidiabetic properties of dietary flavonoids: A cellular mechanism review. Nutr. Metabolism, 12: 1-20. DOI: $10.1186 / \mathrm{s} 12986-015-0057-7$

Wang, Y., S. Chen and O. Yu, 2011. Metabolic engineering of flavonoids in plants and microorganisms. Applied Microbiol. Biotechnol., 91: 949-956. DOI: 10.1007/s00253-011-3449-2

Wang, Z., J. Wang and P. Chan, 2013. Treating type 2 diabetes mellitus with traditional chinese and indian medicinal herbs. Evidence-Based Complementary Alternative Med., 2013: 343594-343594. DOI: $10.1155 / 2013 / 343594$

Wedick, N.M., A. Pan, A. Cassidy, E.B. Rimm and L. Sampson et al., 2012. Dietary flavonoid intakes and risk of type 2 diabetes in US men and women. Am. J. Clin. Nutr., 95: 925-933. DOI: 10.3945/ajcn.111.028894

Wolff, S.P., 1993. Diabetes mellitus and free radicals. Free radicals, transition metals and oxidative stress in the aetiology of diabetes mellitus and complications. $\mathrm{Br}$. Med. Bull., 49: 642-652. PMID: 8221029

WHO, 2016. Global report on diabetes. World Health Organization, France. 
Wright Junior, E., J.L. Scism-Bacon and L.C. Glass, 2006. Oxidative stress in type 2 diabetes: The role of fasting and postprandial glycaemia. Int. J. Clin. Pract., 60: 308-314.

DOI: $10.1111 /$ j.1368-5031.2006.00825.x

Yoshikawa, T. and Y. Naito, 2002. What is oxidative stress? JMAJ, 45: 271-276.

Young, I.S. and J.V. Woodside, 2001. Antioxidants in health and disease. J. Clin. Pathol., 54: 176-86. PMID: 11253127

Yung, L.M., F.P. Leung, X. Yao, Z.Y. Chen and Y. Huang, 2006. Reactive oxygen species in vascular wall. Cardiovasc Hematol. Disord. Drug Targets, 6: 1-19. PMID: 16724932
Zawawi, D.D., H. Ja'afar and A.M. Ali, 2011. Total phenolic compounds and antioxidant properties in different stage of $B$. racemosa and B. spicata leaf. Proceeding of the International Conference on Biology, Environment and Chemistry, (BEC' 11), IACSIT Press, Singapoore, pp: 100-105.

Zheng, S., M. Zhao, Y. Wu, Z. Wang and Y. Ren, 2016. Suppression of pancreatic beta cell apoptosis by Danzhi Jiangtang capsule contributes to the attenuation of type 1 diabetes in rats. BMC Complement Altern. Med., 16: 31-41. DOI: $10.1186 / \mathrm{s} 12906-016-0993-4$ 